\title{
Mineralized and unmineralized calderas in Spain; Part II, evolution of the Rodalquilar caldera complex and associated gold-alunite deposits
}

\author{
J.J. Rytuba ${ }^{1}$, A. Arribas Jr. ${ }^{2}$, C.G. Cunningham ${ }^{3}$, E.H. McKee ${ }^{1}$, M.H. Podwysocki ${ }^{3}$, J.G. Smith ${ }^{1}$, \\ W. C. Kelly ${ }^{2}$, and A. Arribas ${ }^{4}$ \\ 1 U.S. Geological Survey, 345 Middlefield Road, Menlo Park, CA, 94025 USA \\ 2 Department of Geological Sciences, 1006 C.C. Little Building, University of Michigan, Ann Arbor, Michigan, 48109 USA \\ 3 U.S. Geological Survey, 959 National Center, Reston Virginia, 22092 USA \\ ${ }^{4}$ Directorate-General XII, Commission of the European Communities, Rue de la Loi 200, B-1049, Brussels, Belgium
}

Received: December 1989/Accepted: August 3, 1990

\begin{abstract}
The Rodalquilar caldera complex is located in the western part of the Cabo de Gata volcanic field in southeastern Spain and is the first documented example of epithermal gold-alunite mineralization within a caldera in Europe. The Rodalquilar caldera is an oval collapse structure having a maximum diameter of $8 \mathrm{~km}$ and formed at $11 \mathrm{Ma}$ from eruption of the Cinto ash-flow tuff. The oval Lomilla caldera, with a diameter of $2 \mathrm{~km}$, is nested within the central resurgent dome of the older Rodalquilar caldera. The Lomilla caldera resulted from the eruption of the Lazaras ash-flow tuff which was ponded within the moat of the Rodalquilar caldera. The last phase of volcanic activity in the caldera complex was the emplacement of hornblende andesite flows and intrusions. This magmatic event resulted in structural doming of the caldera, opening of fractures and faults, and provided the heat source for the large hydrothermal systems which deposited quartz-alunite type gold deposits and base metal vein systems. The gold-alunite deposits are enclosed in areas of intense acid sulfate alteration and localized in ring and radial faults and fractures present in the east wall of the Lomilla caldera. Like other acid-sulfate type deposits, the Rodalquilar gold-alunite deposits are closely related in time and space to porphyritic, intermediate composition magma emplaced along caldera structures but unrelated to the caldera forming magmatic system.
\end{abstract}

The Miocene Cabo de Gata volcanic field is located along the southeastern coast of spain and is the only extensive area of Tertiary volcanic rocks in Spain. The volcanic field extends for $40 \mathrm{~km}$ along the Mediterranean Sea, and in the western part of the field, regionally extensive rhyolite to dacite ash-flow tuffs, and andesitic stratovolcanoes and cones are present. Three large Valles-types calderas have been identified in the central part of the volcanic field (Rytuba et al. 1988) and the calderas retain much of their original morphology in spite of their Miocene age. The evolution of the essentially unmineralized Los
Frailes caldera and the tectonic setting of the volcanic field is discussed in Part One of this paper. Part Two discusses the detailed geologic evolution of the Rodalquilar caldera complex and its spatial and temporal relationship to epithermal, precious and base metal deposits within the caldera complex. A detailed study of ore deposits and geochemistry of wall rock alteration and ore mineralization is presently underway as a doctoral dissertation by Antonio Arribas Jr. Preliminary results of this study have been published by Arribas et al. (1989).

Earlier studies at Rodalquilar include those by León (1967), Sanchez Cela (1968), Pineda et al. (1981), and Di Battistini et al. (1987). The ore deposits at Rodalquilar have previously been described by Lodder (1966), Sierra and Leal (1968), and Sänger-von Oepen et al. (1989).

\section{Rodalquilar caldera}

The Rodalquilar caldera complex consists of two nested calderas located $8 \mathrm{~km}$ to the north of the older Los Frailes caldera (Cunningham et al. 1990, Part I, Fig. 1). The town of Rodalquilar, after which the caldera complex is named, is located within the southeastern moat of the Rodalquilar caldera. The caldera complex was developed on an older andesitic volcanic field composed of coalescing stratovolcanoes and cones. Flows associated with these stratovolcanoes are the oldest rocks exposed and occur at the base of La Rellana (Fig. 1), a broad plateau composed primarily of out-flow facies ash-flow tuffs from the Rodalquilar caldera. These andesitic rocks are also exposed in the southeast wall of the Rodalquilar caldera. At about $11 \mathrm{Ma}$ in the Rodalquilar area, volcanism in the volcanic field changed in style and composition to the emplacement of dacitic domes. The domes are well exposed outside the north-central wall of the Rodalquilar caldera (Fig. 1). Potassium-argon dating of biotite from one of these domes gives an age of $11.1 \pm 0.4 \mathrm{Ma}$ and places a lower age limit on the development of the Rodalquilar caldera.

After development of the dacitic dome field, a large felsic magma chamber developed beneath the dome field. 


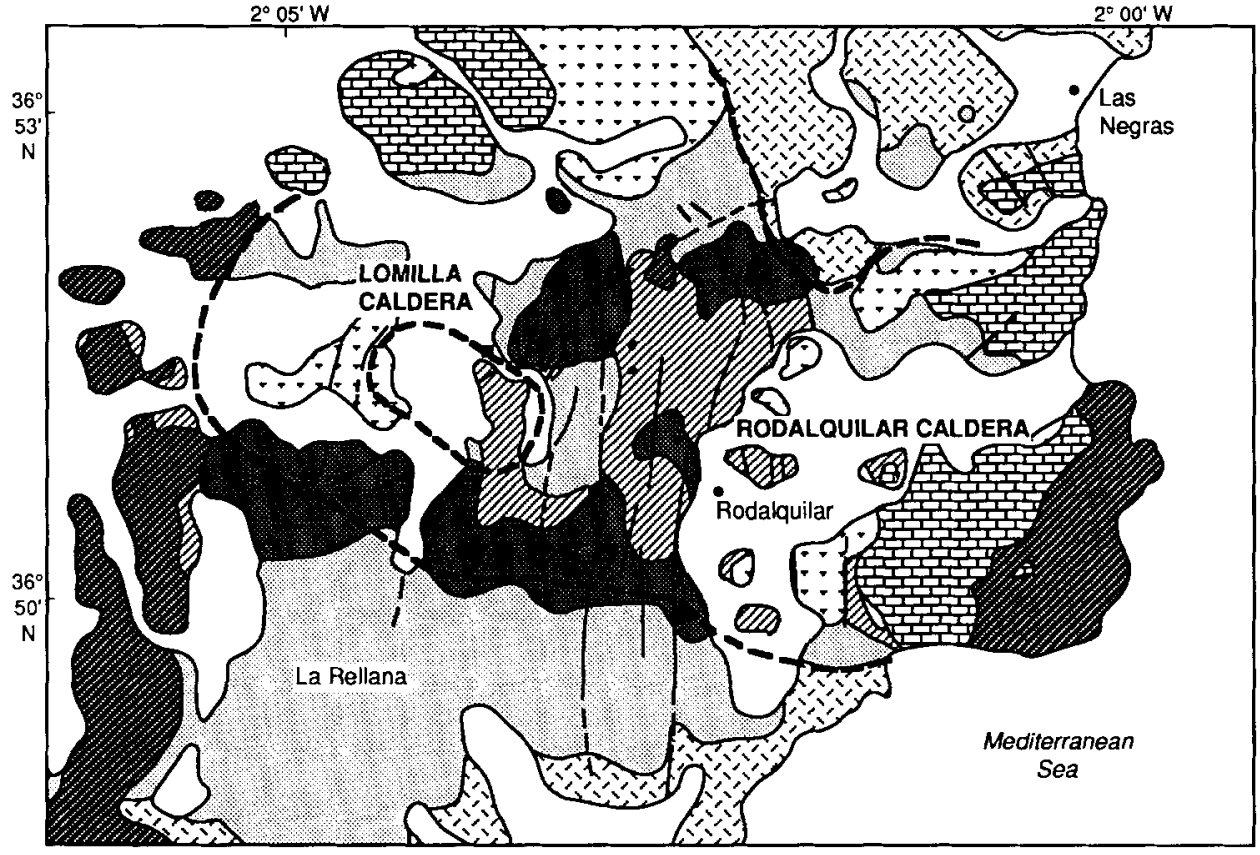

0

$5 \mathrm{Km}$
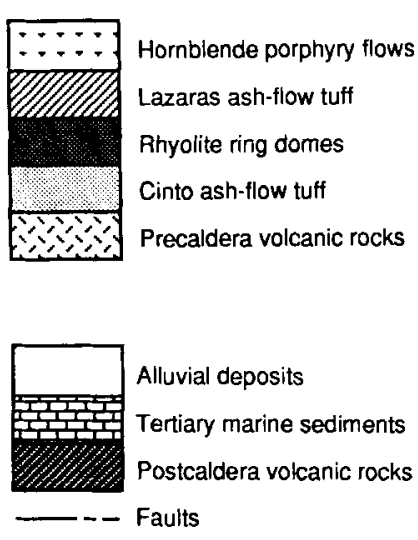

Fig. 1. Geologic map of the Rodaquilar and Lomilla calderas
Eruption of the rhyolitic Cinto ash-flow tuff from this magma chamber resulted in formation of the Rodalquilar caldera, a large Valles-type caldera. The Cinto ash-flow tuff is a composite ash-flow sheet consisting of six cooling units in its outflow facies and a thick sequence of interbedded ash-flows and collapse breccias in its intracaldera facies (Rytuba et al. 1988). The Cinto ignimbrite as originally defined by Lodder (1966) included all rhyolites in the Rodalquilar area with quartz phenocrysts, which included ash-flow tuffs, domes, and flows erupted over a long period of time. The present paper redefines the Cinto ignimbrite to include only the ash-flow tuffs erupted from the Rodalquilar caldera, and to avoid confusion, terms these units the Cinto ash-flow tuff.

The Rodalquilar caldera is an oval collapse structure having a maximum diameter of $8 \mathrm{~km}$ in an east-west direction and a minimum diameter of $4 \mathrm{~km}$ in a northsouth direction (Fig. 1). The morphology of the caldera is still well preserved in its central part but the eastern and western parts are covered by younger marine sedimentary rocks. The south topographic wall of the caldera is well preserved and defined for a strike length of $5 \mathrm{~km}$ by the northern scarp of La Rellana (Fig. 1). Where the topographic wall of the caldera is exposed along the sea coast, unwelded Cinto ash-flow tuff is deposited on precaldera andesite flows (Fig. 2). The contact is gently dipping and reflects erosion of the oversteepened structural wall of the caldera by extensive landsliding of pre-caldera andesite into the caldera. Large blocks of pre-caldera andesite are locally incorporated within the Cinto ashflow and indicate concurrent eruption of the Cinto ashflow with caldera collapse.

The northern structural margin of the caldera is well exposed for a distance of $2 \mathrm{~km}$ (Fig. 1) and is defined by a single, nearly vertical fault that separates pre-caldera domes which form the wall of the caldera from intracaldera Cinto ash-flow tuff and interbedded collapse breccias. The structural margin of the caldera is exposed over a vertical distance of $200 \mathrm{~m}$ and the character of the structural boundary does not change over this vertical interval. The easternmost margin of the caldera is projected to extend into the Mediterranean Sea.

\section{Cinto ash-flow tuff}

A sequence of gently dipping, ash-flow tuffs that overlies pre-caldera andesite flows and breccias occurs in the range extending south of Rodalquilar (Fig. 1). Six ashflow tuff cooling units are exposed and are part of regionally extensive ash-flow sheets. The ash-flow tuffs range from lithic- to pumice-rich. The size of lithic fragments and pumice increases toward the margin of the Rodalquilar caldera and is indicative of near-vent facies, ash-flow tuffs derived from vents localized along the margin of the Rodalquilar caldera. Locally, volcaniclastic sediments and air-fall tuffs separate individual cooling units. The sequence of tuffs consist of six units. Unit one is an unwelded, lithic to pumice rich, aphyric ash-flow tuff which rests on pre-caldera andesite prophyry lava flows. Locally, air-fall tuffs occur at the base of the unit. Unit two is only about 1 meter thick, is partly welded, and contains collapsed green to white pumice in a finegrained, purple ash matrix. Unit 3 is an unwelded lithic ash-flow tuff with lithic fragments up to 1 meter in width (Fig. 3). It is aphyric and similar to unit 1. Unit 4 is a thick, lithic and pumice-rich ash-flow tuff with phenocrysts of quartz and is separated from unit 3 by a thick sequence of air fall tuffs. Unit 5 is an unwelded to partly welded pumice-rich ash-flow tuff with abundant quartz 

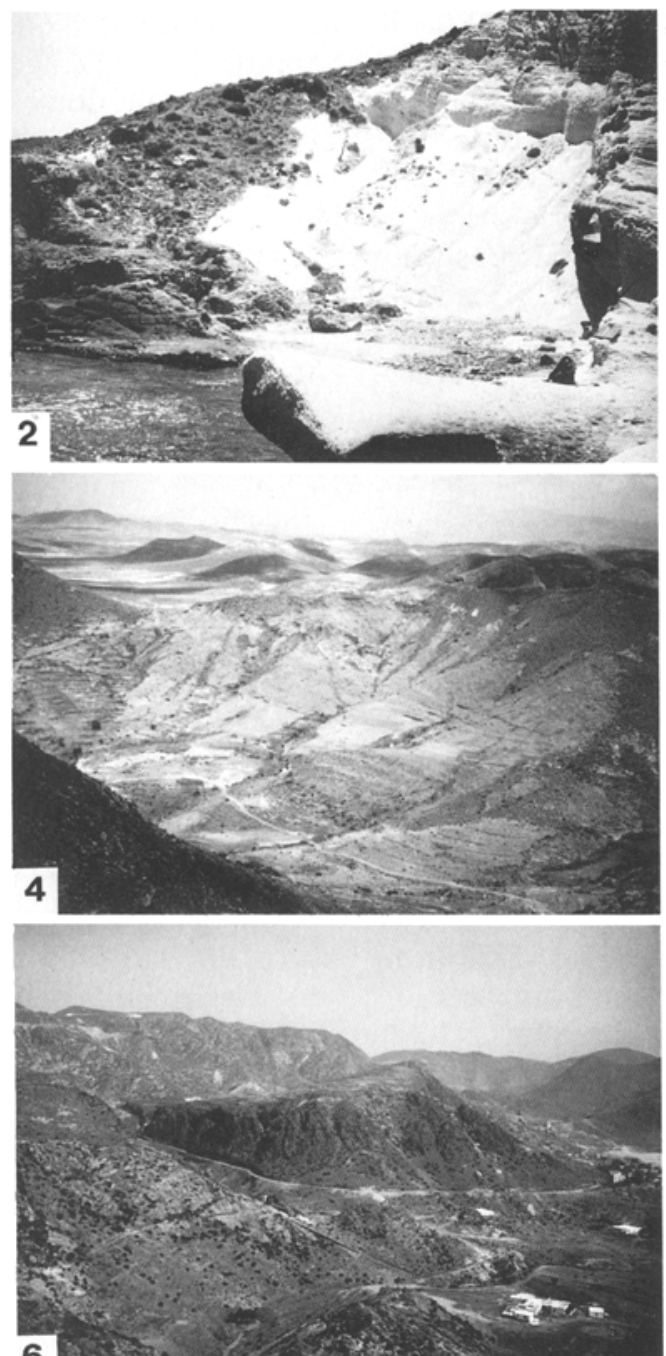

6

Fig. 6. Lazaras ash-flow tuff, dark rocks in central part of photo, filling moat of the Rodalquilar caldera, is deposited on rhyolite ring dome located along southern margin of caldera, foreground. Resurgent dome of Rodalquilar caldera forms skyline on left side of photo. North wall of Rodalquilar caldera forms distant skyline and moat of caldera is low area to right with mill and tailings from gold mine
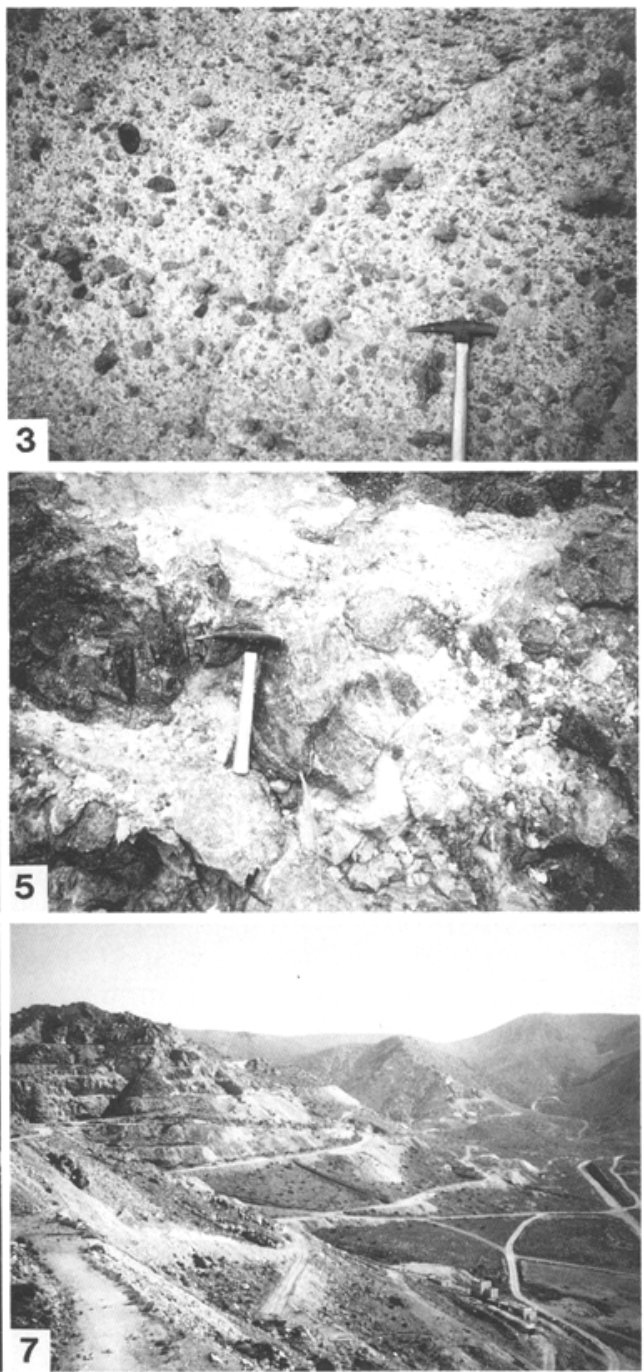

Fig. 2. Southern topographic wall of the Rodalquilar caldera exposed along the sea coast. Cinto ash-flow tuff, white beds, deposited on the gently dipping topographic caldera wall composed of andesite flows, dark rocks. Large lithic fragments of andesite, rigth central part of photo, occur within the tuff (note back-pack and hammer for scale)

Fig. 3. Outflow facies of the Cinto ash-flow tuff, unit 3 , with abundant lithic fragments in a light gray ash and pumice matrix

Fig. 4. Intracaldera Cinto ash-flow tuff interbedded with collapse breccias derived from the Rodalquilar caldera wall located just of 8 the rightside of the photo. Large lithic fragments up to $15 \mathrm{~m}$ in width occur within the collapse breccia, central part of photo

Fig. 5. Collapse breccia bed near Rodalquilar caldera margin consists of large lithic fragments, dark rocks, in a matrix of ash and pumice, light colored fragments

Fig. 7. Rhyolite ring dome located along-central margin of Rodalquilar caldera forms conical hill in far central part of photo. Open cuts in dome are workings along the San Diego gold-quartz vein. South wall of Rodalquilar caldera formed by scarp terminating plateau forming the skyline. Mine workings of gold-alunite deposits in foreground localized in wall of Lomilla caldera

phenocrysts. It has well developed fumarolic vents and has rafted pumice blocks near its top. Unit 6 is a partly to densely welded ash-flow tuff containing abundant large quartz phenocrysts. It is a compound cooling unit and is the ash-flow sheet which creates the table-top topography of the La Rellana and represents the largest volume eruption from Rodalquilar caldera. The large number of cooling units within the Cinto ash-flow tuff indicates that it is a composite sheet.

The intracaldera facies of the Cinto ash-flow tuff is present throughout the central part of the Rodalquilar caldera. Near the northeastern margin of the caldera, more than $200 \mathrm{~m}$ of intracaldera collapse breccias and Cinto ash-flow tuff are well exposed (Fig. 4). The gently dipping beds consist of individual ash-flow tuff beds, the light gray units in Figure 4, and collapse breccia beds, the darker units in the same figure. The individual collapse breccia beds thicken toward the margin of the caldera, located to the right side of Figure 4 and lithic fragments within the collapse breccia reach up to $15 \mathrm{~m}$ in width. Each collapse breccia bed resulted from failure of the oversteepened caldera wall and landsliding of these rocks into the caldera as the eruption of the Cinto tuff continued. The collapse breccia consists of heterogeneous blocks of pre-caldera rocks which formed the wall of caldera in matrix of pumice and ash (Fig. 5) indicating that collapse breccia formation occurred concurrently with eruption on the Cinto ash-flow tuff.

After collapse of the Rodalquilar caldera, resurgence of the central part of the caldera formed a structural dome consisting of intracaldera Cinto ash-flow tuff and collapse breccias. The morphology of the resurgent dome is well preserved and is defined by the high range of hills, Cerro Cinto, which form the skyline in Fig. 6 and reach 
an elevation of 390 meters. The present dip of intracaldera ash-flow tuff along a section extending from the north-central margin of the caldera into the central part of the caldera reflect the structural doming. Near the caldera margin the beds dip inward toward the caldera at 10 degrees; they then become horizontal near the margin of the resurgent dome (central part of Fig. 4), and near the center dip radially outward from the caldera at up to 20 degrees. Structural doming of the central part of the caldera resulted in the formation of a circular, topographic basin (moat) just within the structural margin of the caldera. This is reflected by the area of low topographic relief area in the foreground of Fig. 6.

\section{Ring domes}

After collapse of the Rodalquilar caldera, rhyolite domes were emplaced along the northern and southern structural boundaries of the caldera and locally extended into the caldera (Fig. 1) (Rytuba et al. 1988). Ring domes occupy the entire southern structural boundary of the caldera for a distance of about $5 \mathrm{~km}$. The domes consist of massive, flow-foliated rhyolite which is typically mantled by a carapace of debris avalanche deposits. The domes retain their original morphology (Fig. 7) and have a vertical relief of about $200 \mathrm{~m}$. As shown in Figure 7, the conical shape of the domes strongly contrasts with the topographic wall of the caldera which forms the flat surface on the skyline. Some of the domes attained sufficient height to extend above the elevation of the southern caldera wall. In these areas debris avalanche deposits derived from the rhyolite domes flowed to the south over the rim of the caldera and were deposited on the out-flow facies of the Cinto ash-flow tuff. In the south central part of the caldera the domes emplaced along the southern margin of the caldera (Fig. 1) extended northward into the caldera for a distance of about $1.5 \mathrm{~km}$.

A ring dome emplaced along the north margin of the caldera largely occupies the hill named Cerro de la Hortichuela (Fig. 1). The dome consists of vertically flow foliated rhyolite in the central part of the dome. At the north and west margin of the dome a massive flow was vented and extended into the caldera where it covers intracaldera Cinto ash-flow tuff. To the southwest of the Hortichuela dome, another series of domes extended into the caldera for a distance of about $2 \mathrm{~km}$ from the northern structural margin (Fig. 1).

\section{Lazaras ash-flow tuff and Lomilla caldera}

After ring dome emplacement was complete, eruption of the Lazaras ash-flow tuff (Fig. 1) from vents in the central part of the Rodalquilar caldera resulted in catastrophic failure of part of the central resurgent dome (Rytuba et al. 1988). The ash-flow tuff is partly to densely welded, columnar jointed, and typically contains large fiamme at its base. The pumice generally have a characteristic green color and sparse phenocrysts of quartz and sanidine are present. The Lazaras ash-flow tuff was ponded within the moat of the Rodalquilar caldera where it reaches a maximum thickness of about $90 \mathrm{~m}$. The age relationship of the Lazaras ash-flow tuff to ring domes emplaced along the southern boundary of the Rodalquilar caldera and the structural resurgent dome of the Rodalquilar caldera is shown in Figure 6. The dark, columnar jointed Lazaras ash-flow tuff was deposited on the irregular surface formed by the ring dome, shown in the foreground of Figure 6, and the flank of the resurgent dome of the Rodalquilar caldera. The entire eastern and southern moat of the Rodalquilar caldera, the topographically low area on the right side of Figure 6, was partly filled by the Lazaras ash-flow tuff.

Eruption of the Lazaras ash-flow tuff resulted in the formation of the Lomilla caldera (Fig. 1) an oval collapse structure with a maximum diameter of $2 \mathrm{~km}$ (Rytuba et al. 1988). The Lomilla caldera is nested within the central part of the larger Rodalquilar caldera. The eastern topographic wall of the Lomilla caldera is very well preserved and is defined by an arcuate scarp with over 100 meters of vertical relief that forms the western face of Cerro del Cinto (Fig. 8). The western topographic wall of the caldera is less well preserved and defined by a scarp with a vertical relief of about $70 \mathrm{~m}$ developed along the east facing side of Cerro de la Cruz. The wall of the Lomilla caldera is composed of Cinto ash-flow tuff and interbedded collapse breccias, and rhyolite domes. Arcuate and radial fractures cut the wall of the Lomilla caldera and developed in response to collapse of the Lomilla caldera (Fig. 1).

\section{Caldera-fill sediments, hornblende andesite flows, and associated late-stage resurgence}

After eruption of the Lazaras ash-flow tuff, the moat of the Rodalquilar caldera was filled by a lake and a lacustrine sedimentary sequence consisting of thin bedded shales, tuffaceous sandstones, and diatomite was de-

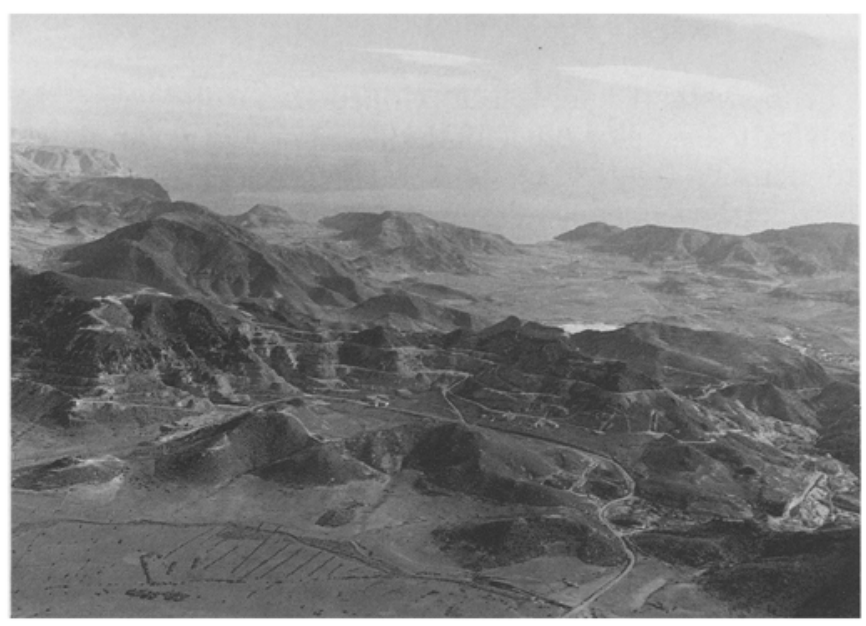

Fig. 8. Eastern topographic wall of the Lomilla caldera is defined by arcuate scarp in central part of photo. Mine workings of the gold-alunite deposits are large open pits in wall of the caldera 
posited. These sedimentary rocks have a minimum thickness of about 10 meters and are locally silicified in the area near the resurgent dome of the Rodalquilar caldera. Local beds of talus breccia derived from the resurgent dome are interbedded with the sediments. The breccias contain clasts of silicified rocks and are up to $10 \mathrm{~m}$ in thickness. The absence of thick interbeds of water-laid ash indicates that little volcanic acitivity occurred within the caldera complex during the early phase of sedimentation within the moat.

Overlying the lacustrine sequence is a pyroclastic unit that is intensely silicified and has a maximum thickness of about 6 meters. The unit is a lithic-rich, ash-flow tuff which was deposited on the nearly horizontal floor of the Rodalquilar caldera moat. At the time of eruption, the lake which had filled the moat of the Rodalquilar had evaporated leaving deposits of gypsum and fine grained clays. Residual waters within the moat of the caldera reacted with the lithic ash-flow tuff resulting in extensive silicification of the tuff during cooling of the unit. The tuff forms a resistant ledge throughout the moat of the Rodalquilar caldera and is a useful stratigraphic marker unit. Exposures in fault blocks along the south moat of the Rodalquilar caldera demonstrate that the silicification is stratigraphically controlled and is most intense in the upper part of the unit. The alteration is unrelated to the hydrothermal systems that developed late in the caldera cycle.

The moat of the caldera was once again filled with water and deposition of a lacustrine sequence consisting dominantly of water-laid tuffs occurred. Volcanic activity again increased in the caldera resulting in the eruption of a sequence of hornblende andesite flows (Fig. 1). The flows range from a few meters to over 50 meters in thickness. The tops of the flows are typically vesicular and the base of the flows commonly consists of flow breccias. Because the flows were deposited on soft sediment, fine grained sediment is often incorporated within the matrix of the flow breccia at the base of the flow. Intrusive plugs and dikes of hornblende andesite were intruded into the wall of the Lomilla caldera (Fig. 1) and are closely associated in time and space to development of large hydrothermal systems that formed the gold deposits within the caldera.

Late stage resurgence within the Rodalquilar caldera occurred near the final stage of emplacement of the hornblende andesitic magma. Evidence for the late stage resurgence is the tilting and doming of the caldera fill sequence consisting of the Lazaras ash-flow tuff, the caldera fill sediments, the pyroclastic flow, and the earliest flows of hornblende andesite flows. The main locus of this late stage doming was in the south central part of the Rodalquilar caldera. In this area, intracaldera Cinto ashflow tuff, interbedded with collapse breccias, has the largest tilts within the caldera. It is likely that north-south trending faults and fractures developed during this resurgence (Fig. 1). This late stage of resurgence was important in opening faults and fractures which were subsequently used as fluid pathways by the large hydrothermal systems which subsequently developed in the caldera (Rytuba et al. 1988).

\section{Marine sediments and pyroxene andesite flows}

The eastern and western margins of the Rodalquilar caldera are covered by a thick sequence of marine sediments consisting of fossiliferous limestones and sandstones (Fig. 1). Incursion of sea water into the caldera occurred after the late-stage resurgence because these strata are not deformed (Fig. 8). The last volcanic event within the caldera was the emplacement of pyroxene andesite flows (Fig. 1) within the eastern part of the Rodalquilar caldera. The andesites have been termed the Los Lobos andesite by Leon (1967) and range in age from 7.5 to $8.5 \mathrm{Ma}$ (Di Battistini et al. 1987). The flows are unaltered ands associated dikes and plugs cut mineralized and altered Cinto ash-flow tuff indicating that this volcanism is post-mineralization in age.

\section{Mineralization and alteration}

The gold-alunite deposits and base-precious metal veins within the Rodalquilar caldera complex are closely associated with a zone of extensive advanced argillic alteration which trends east-west through the Rodalquilar caldera. The zone of alteration is well delineated by Landsat Thematic Mapper data in which color-ratio composite imagery produced from TM5/7, TM5/4 and TM3/1 band ratios are projected as red, blue and green (Rytuba et al. 1988). In this processing of data, zones of intensely altered rocks are shown as white and yellow. Gravity and aeromagnetic highs are coincident with the zone of alteration and reflect the presence of dioritic magma emplaced at the base of the volcanic pile late in the caldera cycle. The extrusive equivalents of this diorite are the hornblende andesites emplaced near the end of volcanic activity in the caldera and this magma is responsible for the last stage of caldera resurgence. The magmatic event is regarded as the heat source responsible for the large hydrothermal cells developed within the caldera.

Ore deposits within the caldera complex (Fig. 9) consist of alunite, gold-alunite, and lead-zinc-silver-gold vein deposits (Arribas et al. 1988). Extensive areas of acid-sulfate alteration occur throughout the Rodalquilar caldera complex but only two areas have been mined exclusively for alunite. The alunite occurs as vein filling, and massive, replacement alunite hosted within intracaldera Cinto ash-flow tuff and collapse breccias and Lazaras ash-flow tuff. The Los Tollos alunite deposits are localized in collapse breccias and intracaldera Cinto ash-flow tuff and Lazaras ash-flow tuff about $0.5 \mathrm{~km}$ from the north-central margin of the Rodalquilar caldera (Fig. 9). The deposits were mined by open pit methods and consist primarily of replacement alunite in which the original texture of the collapse breccia and ash-flow tuff is well preserved. Narrow veins of alunite with minor jarosite are locally present but constitute a minor part of the ore body. On the southeast flank of the resurgent dome of the Rodalquilar caldera, an unnamed alunite deposit was developed in intracaldera Cinto ash-flow tuff and interbedded collapse breccia. The open pit mine was developed in a zone of veining where alunite is present primarily as 


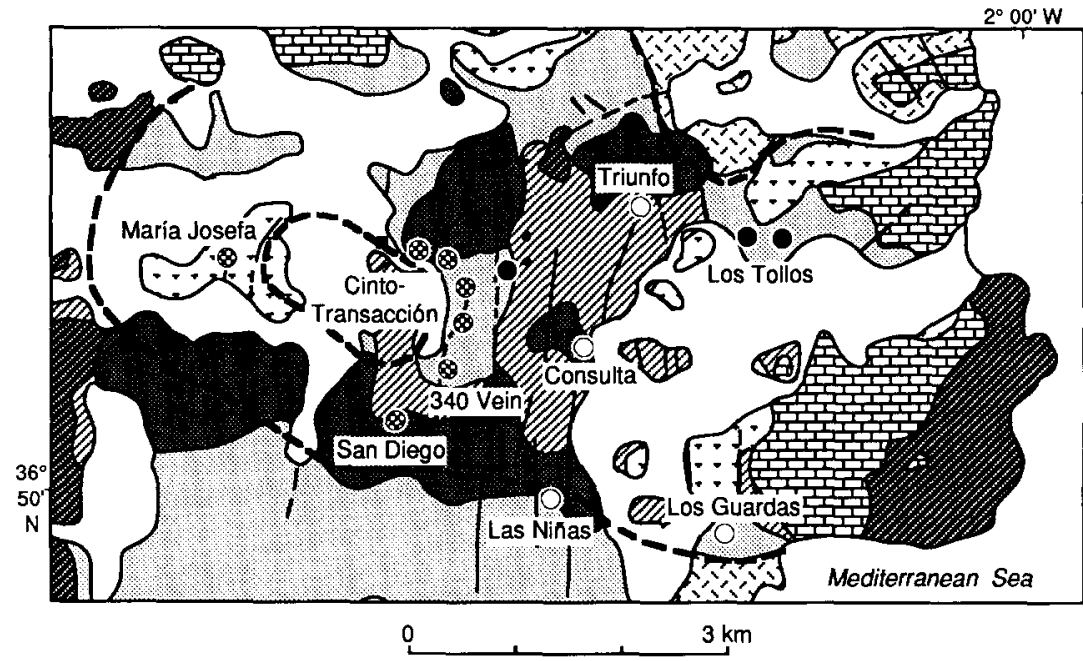

Fig. 9. Location of ore deposits within the Rodalquilar caldera complex. Geological units same as in Figure 1

(2) Au-Ag deposit

Pb-Zn-Ag-Au deposit

Alunite deposit vein filling up to $30 \mathrm{~cm}$ in width. The vein zone was localized along a north-south fracture. Replacement alunite and small alunite veinlets extend outward into the country rock but vein density decreases.

The lead-zinc-silver-gold quartz vein deposits occur along north-south trending faults and fractures which transect all volcanic units within the Rodalquilar caldera complex except the youngest pyroxene andesite flows. The Triunfo vein system which cuts the Lazaras tuff in the north-central part of the Rodalquilar caldera is typical of these. Individual veins are up to $20 \mathrm{~cm}$ wide and occur in a zone about $2 \mathrm{~m}$ width that extends for about $0.5 \mathrm{~km}$ along its strike of $\mathrm{N} 3 \mathrm{E}$. The vein extends northward into the Hortichuela ring dome and altered rocks extend outward from the vein into the country rock at the contact of the Lazaras tuff and ring dome rhyolite. The Consulta vein system is similar to the Triunfo vein and is characterized by massive bands of galena in a quartz gangue. The vein system extends for about $1.5 \mathrm{~km}$ southward from the central part of the Rodalquilar caldera to the south border of the Rodalquilar caldera where it is termed the Las Niñas deposit. It is hosted by rhyolite ring domes and Lazaras ash-flow tuff. Outside the caldera the veins consist of unmineralized amethystine quartz and are hosted by the out-flow facies of the Cinto ash-flow tuff and pre-caldera andesite flows. The Los Guardas vein system is hosted by intracaldera Cinto ash-flow tuff just inside the southeast ring fracture of the Rodalquilar caldera.

The gold-alunite deposits are the most economically important deposits in the caldera complex. About 5 metric tonnes of gold were produced in the period from 1943 to 1966 from these deposits and current announced reserves of gold for the Transacción mine consist of 650000 tonnes of ore averaging 2.5 grams per ton (Skillings Mining Review 1988). The gold-alunite deposits are primarily localized in ring and radial faults and fractures present in the east wall of the Lomilla caldera. Four main open pits and associated underground workings have been developed in the wall of the Lomilla caldera (Fig. 8 and 9). The gold-alunite deposits in the wall of the Lomilla caldera are hosted by intracaldera Cinto ash-flow tuff interbed- ded with collapse breccias and the northernmost deposits are partly hosted by a rhyolite ring dome which extends into the caldera. The deposits are closely associated with plugs and dikes of hornblende andesite which intrude the intracaldera tuffs and breccias. These intrusive rocks are altered and locally mineralized. Gold mineralization occured in association with the formation of chalcedony veinlets and fracture coatings which cross cut acid-sulfate altered rocks. The gold mineralization extended over a vertical interval of about $200 \mathrm{~m}$ and mineralization changes at depth to a complex sulfide assemblage with only trace amounts of gold. Altered rocks in the ore zone formed from pervasive acid sulfate alteration and consists of an assemblage of quartz, alunite, kaolinite, jarosite, pyrophyllite and hematite. Along faults and fractures the country rock is completely leached and consists of vuggy silica. Below the zone of mineralized rocks, acid-sulfate altered rocks grade into argillically altered rocks. Outside the main zone of gold-alunite mineralization, higher grade gold veins, over $20 \mathrm{~g}$ per tonne, extend into the ring domes located along the southern margin of the Rodalquilar caldera. The San Diego gold vein is localized in a ring dome emplaced just north of the south-central margin of the Rodalquilar caldera (Fig. 9). The zone of mineralization has a maximum width of $8 \mathrm{~m}$ and consists of a silicified fracture zone which strikes N $45 \mathrm{E}$. It is defined by extensive mine workings developed along the vein shown in Figure 7 . The 340 vein is a hydrothermal breccia up to $2.5 \mathrm{~m}$ in width which contained up to $500 \mathrm{~g}$ per tonne of gold. The hydrothermal breccia contains fragments of silicified rock cemented by chalcedony. It is hosted in collapse breccias and is localized along a northeast trending fracture zone. The Maria Josefa vein consists of two black chalcedony veins with a total width of $2 \mathrm{~m}$. It is localized in hornblende andesite flows. None of the underground workings which exploit these veins extended below $100 \mathrm{~m}$ of the present surface, indicating that mineralization was restricted to the near surface.

Based on stratigraphic contraints, the age of all three types of mineralization within the Rodalquilar complex is younger than the Lomilla caldera and sedimentary and volcanic rocks which fill the moat of the Rodalquilar 
caldera. The mineralization is closely associated with hornblende andesite intrusives and flows, the youngest volcanic rocks within the moat fill sequence of the Rodalquilar caldera. Only some of the hornblende andesite flows are altered and mineralized indicating that mineralization occurred during the early phase of andesitic volcanism but ended before the last flows were emplaced at $9.0 \pm 0.6 \mathrm{Ma}$. The youngest volcanic rocks in the caldera complex are unaltered pyroxene andesite flows which occur in the eastern part of the Rodalquilar caldera and have an age of 8.4 to $7.5 \mathrm{Ma}$ (Bellon et al. 1983; Di Battistini et al. 1987). Potassium-argon dating of alunite and illite from the alteration zones associated with gold deposits in the wall of the Lomilla caldera range from $9.5 \pm 0.5 \mathrm{Ma}$ to $11.3 \pm 0.4 \mathrm{Ma}$ for illite and $10.3 \pm 0.4 \mathrm{Ma}$ to $10.6 \pm 0.5 \mathrm{Ma}$ for alunite and have an average age of $10.8 \pm 0.5 \mathrm{Ma}$ (Arribas et al. 1989). Development of large hydrothermal systems within the Rodalquilar caldera complex occurred during emplacement of hornblende andesitic magma at the waning stage of the caldera cycle. Emplacement of the andesitic magma resulted in structural doming of the central and southern part of the Rodalquilar caldera and was important in opening faults and fractures which were used as fluid pathways by the hydrothermal systems.

\section{Conclusions}

The late stage development of mineralization in the evolution of the Rodalquilar caldera complex is consistent with observations of other mineralized calderas (Rytuba 1981). Mineralization in caldera systems typically is associated with the last phase of volcanism within the caldera and unrelated to the caldera-forming magmatic system. Other gold-alunite type deposits also occur in large caldera systems, for example Summitville (Stoffregen 1987) and Goldfield (Ashley 1974), U.S.A., and Kasuga, Japan (Izawa and Cunningham 1989). Like the Rodalquilar gold-alunite deposits, these deposits are closely related in time and space to porphyritic, intermediate composition magma emplaced within caldera structures but unrelated to the caldera-forming magmatic system. The importance of these porphyritic, intermediate intrusions to the mineralization process is also documented by the absence of this type of magmatism and mineralization in the Los Frailes caldera described in the companion paper, Part $I$, in this volume.

Acknowledgements. This work represents part of the results of a joint U.S. Geological Survey-Spain, multidisciplinary project on the origin of gold-alunite deposits. Project members included participants from the U.S. Geological Survey, University of Michigan, University of Salamanca, and Empresa Nacional "Adaro" de Investigaciones Mineras SA (ENADIMSA). The authors are indebted to (ENADIMSA) and St. Joe Transaccion for their sincere cooperation with this study.

\section{References}

Arribas, A., Jr., Rytuba, J.J., Rye, R.O., Cunningham, C.G., Podwysocki, M.H., Kelly, W. C., Arribas, A., McKee, E. H., Smith, J.G.: Preliminary study of the ore deposits and hydrothermal alteration in the Rodalquilar caldera complex, southeastern Spain, U.S. Geological Survey Open-File Report 89-327, 39 p. (1989)

Arribas, A., Jr., Rytuba, J.J., Cunningham, C.G., Kelly, W.C., Rye, R.O., Castroviejo, R.: Rodalquilar deposits, Spain, First example of caldera-related epithermal gold mineralization in Europe: Part 2, Ore Genesis (abs.): Geological Society of America Abstracts with Program, v 20, no 7, p. A351 (1988)

Ashley, R.P.: Goldfield mining district, in: Guidebook to the geology of four Teritary volcanic centers in central Nevada: Nevada Bureau of Mines and Geology Report 19, p. 49-66 (1974)

Bellon, H., Bordet, P., Montenat, C.: Chronologie du magmatisme Neogene des Cordilleres Betiques (Espagne meridionale): Bull. Soc. Geol. France 25:205-217 (1983)

Cunningham, C.G., Arribas, A., Jr., Rytuba, J.J, Rye, R.O., Kelly, W.C., Podwysocki, M.H., McKee, E.H., Arribas, A., Sr., Castroviejo, R.: The origin of United States-Spain gold/alunite deposits: The caldera-related epithermal gold/alunite deposits at Rodalquilar, Spain (abs.): 28th International Geologic Congress Abstracts and Program, 4 p. (1989)

Di Battistini, G., Toscani, L., Iaccarino, S., Villa, I.M.: K/Ar ages and the geological setting of calc-alkaline volcanic rocks from Sierra de Gata, SE Spain: Neues Jahrbuch für Mineralogie, Monatsheft 8:369-383 (1987)

Izawa, E., Cunningham, C.G.: Hydrothermal breccia pipes and gold mineralization in the Iwashita ore body, Iwata Deposit, Kyushu, Japan: Econ. Geol 84:715-724 (1989)

León, C.: Las formaciones volcánicas del Cerro de los Lobos (Almeria, S.E. de Españna): Estudios Geológicos 23:14-28 (1987)

Lodder, W.: Gold-alunite deposits and zonal wall-rock alteration near Rodalquilar, SF Spain: Meded. University Amsterdam, Geol. Inst., v. 318, 93 p. (1966)

Pineda, A., Giner, J., Goy, J.L., Zazo, C.: Mapa geológico de España a escala $1: 50000,2^{\text {a }}$ Serie (MAGNA) No. 1046 (Carboneras), Instituto Geológico y Minero de España (1981)

Rytuba, J.J.: Relation of calderas to ore deposits in the western United States, in: W. R. Dickinson ed. Relations of Tectonics to Ore Deposits in the Southern Cordillera: Arizona Geological Society Digest 14:227-236 (1981)

Rytuba, J.J., Arribas, A., Jr., Cunningham, C.G., Podwysocki, M.H., McKee, E.H., Arribas, A. Sr.: Rodalquilar deposits, Spain, first example of caldera-related epithermal gold mineralization in Europe: Part I, Caldera evolution (abs.): Geological Society of America Abstracts with Program, v. 20, no. 7, p. A351 (1988)

Sanchez Cela, V.: Estudio petrológico de las sucesiones volcánicas del sector central de la formación del Cabo de Gata (Almeria): Estudios Geológicos 24:1-38 (1968)

Sänger-von Oepen, P., Friedrich, G., Vogt, J.H.: Fluid evolution, wall rock alteration, and ore mineralization associated with the Rodalquilar epithermal gold deposits in Southeast Spain: Mineral. Deposita 24: 235-243 (1989)

Sierra, J.G., y Leal, G.: El distrito aurífero de Rodalquilar, Cabo de Gata. Geología, metalogenia, geoquimica e investigaction minera: Informe interno. E. N. Adaro, Madrid (1968)

Skillings Mining Review: Cluff/Antofagasta developing Transacción gold mine in Spain: v. 77, no. 13, March 26 (1988)

Stoffregen, R.E.: Genesis of acid-sulfate alteration and $\mathrm{Au}-\mathrm{Cu}-\mathrm{Ag}$ mineralization at Summitville, Colorado: Econ. Geol. 82:15751591 (1987) 